\title{
1 The Feminist Foundations of Language, Gender, and Sexuality Research
}

\author{
MARY BUCHOLTZ
}

\section{Introduction: Linguistics and Feminism}

Feminist linguists have been in dialogue with feminists in other disciplines since the field's formation, yet this historical relationship and its implications for current work are only occasionally highlighted in scholarship. This chapter reaffirms the feminist foundations of a wide range of research on language, gender, and sexuality by highlighting and illustrating the numerous, sometimes clashing, and often not fully articulated feminist positionings taken up within various studies over the course of the field's development.

Because the term "feminism" is often misunderstood, I offer the following definition:

Feminism: a diverse and sometimes conflicting set of theoretical, methodological, and political perspectives that have in common a commitment to understanding and challenging social inequalities related to gender and sexuality.

Although "feminism" often appears in the singular, its reference is always plural; there is no unified feminist theoretical, methodological, or political perspective. Yet, despite the often vigorous and heated debates between different versions of feminism, they share a commitment to addressing social inequality. Furthermore, the field of language, gender, and sexuality is both unified and divided in precisely the same way as is feminism itself: more or less unified in its general political goals, divided in the perspectives it takes toward achieving those goals. But despite this broad scope, not all scholarship on the intersection of language with gender and sexuality is part of the field, because not all of it shares a political commitment to social justice. Indeed, a sizable body of traditional social science research seeks

The Handbook of Language, Gender, and Sexuality, Second Edition. Edited by Susan Ehrlich, Miriam Meyerhoff, and Janet Holmes.

(c) 2014 John Wiley \& Sons, Ltd. Published 2014 by John Wiley \& Sons, Ltd. 
simply to correlate language patterns with categories of gender and/or sexuality and does not engage meaningfully either with feminist theory or with feminist linguistics. ${ }^{1}$

The chapter is organized according to three significant bodies of feminist thought that emerged in the late twentieth and early twenty-first centuries: difference feminisms, which take gender difference as their starting point and focus on the position of women within structures of gender; critical feminisms, or critiques or extensions of difference perspectives that nevertheless share certain commonalities with them; and queer feminisms, which refocus the field on the problematization of gender and its relationship to sexual identities and practices. Although a rough chronology could be imposed on these frameworks, the following discussion is not primarily a historical account, since all of the feminist theories considered here remain in active use and development by feminist academics and activists of various stripes. Feminist studies is an extremely dynamic field, and inevitably all of these theories have come in for a great deal of critique by those that have come later (as well as by their predecessors). Nevertheless, all of them have value for current feminist linguistic scholarship and activism. For this reason, researchers must be wary of unreflexively privileging certain forms of feminism over others in our study of language, gender, and sexuality.

The following discussion focuses on linguistic scholarship and feminist theory in the English-speaking world, and particularly in the United States, the tradition with which I am most familiar. It is hoped that this preliminary sketch will inaugurate a larger discussion of the relationship between feminist theories and empirical research on language, gender, and sexuality in diverse intellectual traditions around the globe. For the most part, I have set aside approaches that have been influential in feminist theory but have had relatively little impact on the empirical linguistic study of gender and sexuality. Most prominent among these are the poststructuralist theories of language advanced by French feminist literary theorists and philosophers influenced by the psychoanalytic work of Jacques Lacan (Marks and de Courtivron 1980; for some empirical linguistic perspectives on this general approach, see, e.g., Hass 2000; Livia 2000; Livia, Chapter 30 in this volume).

The brief descriptions of each theory presented below are intended to give a sense of the varied concerns of different branches of feminist thinking rather than to provide absolute criteria for one approach versus another. The discussion foregrounds individuals whose work has become iconic of particular theoretical perspectives; more detailed overviews of feminist theory offer a fuller account of the issues explored here (e.g., Beasley 1999; Jackson and Jones 1998; Tong 2009). Likewise, my discussion of specific linguistic studies in relation to specific brands of feminism necessarily highlights some aspects over others and focuses on only a small subset of the scholarship of the researchers under discussion. The reader should consult these scholars' full body of work for a more complete picture.

The following discussion is in some ways a continuation and extension of a conversation between feminist theory and theories of language that Deborah Cameron launched over 25 years ago. Her pathbreaking book Feminism and Linguistic Theory 
(1985) articulated the theoretical and political grounds for linking language and gender in both scholarship and activism and demonstrated the deep linguistic roots of feminist questions. Cameron's work was an important early step in what became a revolution in feminist linguistics. Thanks to developments in feminist theory that are further discussed later in the chapter, by the 1990s language had become central to feminist theorizing not only in France, where the issue had long been explored, but also in the English-speaking world. In the same period, feminist theory became more explicitly central to empirical linguistic investigations than ever before. Before examining this turn of events, however, it is necessary to consider the feminist foundations of language, gender, and sexuality studies from the very beginning of the field.

\section{Difference Feminisms}

Many Anglo-American feminist theories of the 1960s through the 1980s grew out of the political movement that has been dubbed second-wave feminism, which built on the advances of the first-wave feminist movement of the nineteenth and early twentieth centuries. Although primarily fueled, like all feminist thought and action, by real-world political goals, second-wave feminism had intellectual underpinnings in a range of feminist theories that responded both to the political changes of the time and to developments within the academy. These theories include liberal feminism, cultural feminism, and radical feminism. What unifies these forms of second-wave feminism is a focus on gender difference as the foundation of feminist thinking. Where they diverge, however, is in their understanding of this difference and how it should be addressed by feminists.

\subsection{Liberal feminism and women's language}

The form of feminism that is currently most widely advocated by nonfeminists albeit generally not under this label - is liberal feminism. The primary goal of liberal feminism is to establish equality between women and men in all aspects of society by eradicating barriers to women's full participation; thus, it does not seek to change the structure of society but rather to provide equal opportunities for women within existing social structures. Unlike many of the other feminist theories discussed in this chapter, liberal feminism has taken its primary inspiration from public advocates and popular commentators rather than from the academy (e.g., Friedan 1963). At the same time, much of the mainstream - as opposed to overtly feminist - scholarly research on gender continues to be directly or indirectly informed by broadly liberal feminist goals.

Indeed, the success of liberal feminism in integrating feminist viewpoints into public discourse and policy during the latter half of the twentieth century is evident in the fact that it is often no longer recognized as feminism at all. For example, as many feminist linguists know only too well from our experiences of teaching 
undergraduate classes, many younger women - and men - reject the label "feminism" for themselves while embracing its goals (Houvouras and Carter 2008). And even a number of conservative political figures in the United States espouse liberal feminist principles of gender equality, although they do not generally support policies designed to uphold these principles.

While liberal feminism has made important strides in establishing equality for all women through its focus on such fundamental issues as equal pay, abortion rights, and domestic violence, its impact has been particularly significant for middle-class women, who have benefited from liberal feminist efforts to expand women's access to traditionally male institutions of influence and power such as politics, the law, and professional workplaces. Given its concern to bring women into men's spheres, liberal feminism has generally aimed to eradicate gender inequality by eradicating or at least reducing gender difference. Beginning in the 1970 s and 1980s, some attempts to advance this notion, particularly in middle-class workplaces, had the unintended consequence of encouraging women to look, act, and speak more like men, producing a widely circulating stereotype of "ball-busting bitches" dressed in broad-shouldered power suits. Thus, despite some liberal feminists' early advocacy of androgyny for both women and men as an escape from the constraints of gender roles, in practice, efforts to eliminate gender differences have sometimes resulted in societal expectations that women must adapt to male norms.

Liberal feminism was also extremely influential in the early foundations of language, gender, and sexuality research, an impact that continues to the present day. Perhaps the most widely discussed aspect of liberal feminist linguistics has been the controversial - yet at least partly successful - effort to eradicate the most overt forms of sexism in the English language. These include the use of the masculine as a generic form and gendered agent nouns like fireman, as well as status asymmetries in the semantics of gendered pairs like master/mistress and major/majorette (e.g., Frank and Treichler 1989; Lakoff 2004 [1975]; Miller and Swift 1977; Pauwels 1998). However, within the field the concern with women's ways of using language eventually overshadowed this issue.

The primary figure associated with liberal feminist linguistics is Robin Lakoff, whose text Language and Woman's Place (2004 [1975]) played a crucial role in establishing the study of language, gender, and sexuality as a linguistic subfield. ${ }^{2}$ This pioneering book has been nevertheless widely criticized by both feminist and nonfeminist linguists on a number of theoretical, political, and methodological grounds (for discussions, see, e.g., Bucholtz 2004; Bucholtz and Hall 1995), and it has especially been targeted for what critics have viewed as a privileging of male linguistic norms and a devaluing of women's linguistic practices. In fact, however, Lakoff is not endorsing but simply describing a culture-wide ideology that scorns and trivializes both women and women's ways of speaking. Her work has served as a touchstone for the field for over 30 years thanks to its cogent characterization of "women's language" as a set of ideologically saturated linguistic practices constraining women's ability to participate in male domains. As she puts it, "women are systematically denied access to power, on the grounds that they 
are not capable of holding it as demonstrated by their linguistic behavior" (2004 [1975], 42). Scholars continue to debate the concept of "women's language" as well as the empirical evidence for and against the claims Lakoff made about its specific features, from the use of hedges and tag questions to women's perceived inability to tell jokes. Nevertheless, her broader concern with the ideological effects of language in disempowering women remains an important liberal feminist contribution.

More recent work that shares some aspects of this general perspective is Judith Baxter's (2010) research on the speech of women who hold leadership positions within the business world. While importantly informed by other feminist theories in addition to liberal feminism, Baxter's analysis aligns with this approach in calling attention to the way that gender ideologies in male-dominated workplaces limit women's access to corporate power. Her finding that women in such workplaces must constantly monitor their language is reminiscent of Lakoff's double bind, whereby "a woman is damned if she does [speak in accordance with gender ideologies] and damned if she doesn' $t$ " (2004 [1975], 85). Thus liberal feminist issues have continued relevance in research on language, gender, and sexuality even as contemporary scholars expand their theoretical toolkit to include other perspectives as well.

\subsection{Cultural feminism and gendered interactional styles}

While liberal feminism concentrates on the downplaying of gender difference in order to achieve gender equality, another second-wave theory, sometimes termed "cultural feminism" (though generally not by those to whom it is applied), instead views women's ways of thinking, acting, and speaking as distinctive and inherent qualities that should be valorized by scholars and society (e.g., Belenky et al. 1986; Gilligan 1982). These practices have often been attributed to a distinct women's culture, said to be rooted in early socialization experiences as well as in women's biological potential to be mothers and hence nurturers.

Because cultural feminism takes somewhat different forms, it is useful to distinguish between liberal cultural feminism and radical cultural feminism. Liberal cultural feminism, like liberal feminism more generally, advocates equality between the genders; however, where other forms of liberal feminism promote gender equality via the reduction of gender differences, liberal cultural feminism seeks acknowledgment of the equal value of what are seen as women's distinctive practices.

Within linguistics, the most prominent representative of a liberal cultural feminist approach is Deborah Tannen, whose bestselling book You Just Don't Understand (1990) catapulted the study of language and gender to international awareness. Tannen's basic claim both in this popular text and in her scholarly writings on gender (e.g., Tannen 1994) is that women and men in intimate heterosexual relationships often miscommunicate because of different gendered interactional styles. In particular, she proposes that women have a cultural preference for cooperative, egalitarian interaction and for "rapport talk," or emotion-based, connection-oriented communication, while men have a preference for competitive, 
hierarchical interaction and "report talk," or fact-based, information-oriented communication. (See Tannen, Chapter 25 in this volume.)

Tannen's analysis of heterosexual interaction is deeply influenced by earlier work that proposed that gender differences stem from early childhood cultures, in girls' and boys' gender-segregated play groups (e.g., Maltz and Borker 1982). Critics have argued that girls' interaction may be characterized by both cooperation and competition. Such varied practices complicate but do not entirely refute cultural feminist linguistic analysis, which is often more nuanced than its representations in popular and secondhand recirculations would suggest. Indeed, some liberal cultural feminists have argued that the often Machiavellian politics of girls' social worlds may work hand in hand with an ethos of cooperation and egalitarianism among ingroup members (Simmons 2002; for an alternative perspective, see Goodwin 2006; Goodwin and Kyratzis, Chapter 26 in this volume).

As with Lakoff's work, which has also reached a wide audience, Tannen's research has been more warmly received outside of the academy than within it, and once again feminist linguists in particular have been highly critical of the book's theory, methodology, and politics as well as skeptical of its author's feminist credentials (e.g., Davis 1996; 1997; Freed 1992; Troemel-Ploetz 1991; Uchida 1992; for a defense of Tannen, see Yerian 1997). ${ }^{3}$ Because her primary goal has been to help individual women and men address difficulties in their personal relationships by becoming more aware of gendered interactional differences, some feminist critics perceive Tannen's approach as apolitical, and they charge her with encouraging women, who are more likely to read her book and follow her advice, to accommodate to male norms. Nevertheless, Tannen certainly had feminist goals in writing the book and made clear that she viewed women's interactional style as just as legitimate as men's. In this regard, her perspective is closely aligned with that of liberal cultural feminists in other disciplines.

The second form of cultural feminism, radical cultural feminism, shares with its liberal counterpart a view of women's ways of thinking, speaking, and acting as distinctive from men's. However, rather than treating the two genders as equal, the radical version of cultural feminism elevates women's practices over men's, often grounding this position in women's reproductive capacity. Focusing on what they view as women's superior cognitive, affective, and experiential relationship to the world, radical cultural feminists have argued that a women-led, or even a women-only, society would be far preferable to male domination (e.g., Daly 1978). As part of imagining this new utopia, some radical cultural feminists even created a new lexicon that placed women's concerns at the center of language (e.g., Daly and Caputi 1987).

Within linguistic research, however, the focus of radical cultural feminist analysis has been more concerned with interaction than lexis, and most scholars who have taken up this perspective in their work, while extolling women's interactional abilities, do not align themselves with the more provocative utopian politics of some strands of radical cultural feminism (but see Penelope 1990). For example, Janet Holmes offers what she describes as a "tongue-in-cheek" counterpoint to Chomsky by proposing that "New Zealand women constitute 
ideal speaker-hearers," or at least "attractive conversational partners" $(1993,111)$. Through a quantitative comparison of women's and men's interactional practices based on data collected in New Zealand, Holmes finds that women are more attentive to their interlocutors' face needs, producing more positive-politeness hedges, more facilitative tag questions, and fewer interruptions, among other practices. While a Lakoffian liberal feminist perspective would argue that such practices are indexical of powerlessness, Holmes rejects this view, although she acknowledges that women's interactional dexterity may work to men's advantage in conversation due to a general male "lack of interactive sensitivity" (1993, 112; see also Fishman 1983). By inverting the liberal feminist understanding of women's linguistic practices as the interactional apparatus of gender subordination, Holmes offers a valuable counterpoint that positions women as skilled and agentive language users.

A second linguistic study that draws on radical cultural feminist principles is Jennifer Coates's (1996) work on talk in women's friendship groups. Her book Women Talk ends with a powerful statement of the value and significance of women's talk: "It is the radical potential of women's friendships that makes them worthy of close investigation. They can be seen as a model of the way relationships should be, of the way relationships might be in the future" (Coates 1996, 286). Coates's celebratory tone echoes Holmes's positive assessment of women's special interactional abilities as well as the utopian vision articulated by radical cultural feminist theory. Such work once again provides an important alternative to the more pessimistic view of women's interactional practices found in liberal feminism.

At the same time, given the vast variety of women's speaking styles, numerous individual women and even entire cultural groups do not conform to the characterizations presented by these scholars, and it is unclear whether theories of female linguistic superiority can accommodate such speakers (Bucholtz 1999). Such claims are better seen as political strategies to enhance awareness and appreciation of (some) women's interactional practices. While idealizing women's interaction can lead to the establishment of an intragender hierarchy in which some women are problematized and marginalized, this move also calls attention to women's skills. Radical cultural feminists within linguistics have therefore made an important theoretical and political contribution by celebrating the often undervalued interactional practices associated with many women. The ongoing influence of this perspective is evident in the growing effort among feminist linguists to highlight women's and girls' linguistic abilities.

\subsection{Radical feminism and linguistic violence}

The final second-wave feminist theory I consider here is radical feminism, of which radical cultural feminism is a special case. Where radical cultural feminism focuses on the unique situation of women, sometimes even to the exclusion of any consideration of men, the more general form of radical feminism keeps its focus squarely on the relation between women and men. Radical feminism is what most members 
of the public think of when they hear the term "feminism" and is presumably part of the reason that many people do not identify as feminists; in part this situation is due to the fact that "radical feminist" has become an epithet hurled by hostile right-wing commentators. Yet the principles and goals of radical feminism are quite different from those ascribed to it in highly distorted popular representations. What makes radical feminism radical is not its goals but its founding principles; here radical means not "extreme" but "root." For radical feminists, the root cause of social inequality is gender inequality, which is based in men's systematic and structural subordination of women, or patriarchy. It is crucial to recognize that in radical feminist thought, patriarchy is not simply the power of individual men over individual women but a system of oppression from which every man benefits in countless ways, even without recognizing or intentionally participating in this system. Thus individual men sympathetic to feminist aims cannot simply renounce their patriarchal privilege.

The leading theorists of radical feminism are many, but I focus here on two influential figures, Susan Brownmiller (1975) and Andrea Dworkin (1974), who argue that male sexualized violence against women is the very cornerstone of patriarchy, allowing men to maintain their dominant position over women. Although Brownmiller distinguishes rape, as an act of power, from sex, as an act of eroticism, Dworkin (1987) takes a stronger position, arguing that all heterosexual intercourse under patriarchy is necessarily coercive. Dworkin's perspective has not been widely embraced in feminist circles, but Brownmiller's characterization of rape as rooted in power rather than desire has not only shaped feminist thinking but also helped to transform the understanding of rape within the law, the media, and the culture at large. At the same time, sexist and misogynistic misperceptions about rape and its victims continue to circulate widely, an issue in which language is paramount.

The linguistic dimensions of rape as a radical feminist issue are investigated in Susan Ehrlich's scholarship on language and sexual violence (e.g., Ehrlich 2001; Chapter 23 in this volume). Ehrlich's work demonstrates the payoff for feminist linguists in engaging directly with feminist theory and research in other fields. Building on insights from Susan Estrich (1987) and other feminist researchers, Ehrlich convincingly shows how the discourse of rape culture permeates the legal system in ways that structurally disadvantage female rape survivors. ${ }^{4}$

In the view of radical feminism, the threat of such violence is evident not only in acts of rape and sexual assault but also through mundane linguistic practices discussed by a number of scholars, like street remarks (e.g., Gardner 1980; Kissling 1991) and sexual harassment in workplace settings (e.g., Ragan et al. 1996) and online (e.g., Herring 1999; Herring and Stoerger, Chapter 29 in this volume). At the same time, influential feminist linguistic research has argued that men also engage in acts of conversational domination over women such as interruption, lack of uptake of women's topics, and problematizing of women (Fishman 1983; Ochs and Taylor 1995; Spender 1985). Although radical feminism has been critiqued for its emphasis on the subjugation of women under patriarchy to the exclusion of other issues, its insights into the mechanisms of gendered power remain directly 
relevant to feminist linguists' efforts to combat linguistic and physical violence (e.g., Kitzinger and Frith 1999; Trinch 2003).

\section{From Gender Difference to Gendered Experiences}

Within linguistics, second-wave feminist approaches are widely classified according to a broad three-way taxonomy of deficit (liberal feminism), difference (cultural feminism), and dominance (radical feminism) (Cameron 1995). While this tripartite categorization highlights some of the important distinctions among these perspectives, it obscures what they share: All three of these forms of second-wave feminism are in fact "difference" approaches, in that they take gender difference as their starting point. Relatedly, all three theories position women's experiences both as universally shared and as central to feminist inquiry. This perspective is often criticized as essentialism, which in the case of gender posits a shared cultural "essence" that unites all women and differentiates them from men. Such an approach was necessary in the early years of second-wave feminism in order to establish gender as a relevant topic for scholarship and to bring women into focus across the academy, and this form of analysis remains a valuable tool of feminist research if its limitations are recognized. Yet in foregrounding the category of women, the second-wave perspective underplays other important aspects of gender. I now turn to alternative frameworks that broaden the scope of feminist critique both to include issues of race and class as well as gender and to encompass the analysis of masculinity and men's experiences alongside the traditional focus on women. Unlike second-wave feminist linguistics, which is often associated with a few iconic figures, these new approaches have been pursued by many different scholars from a number of angles. For the most part I therefore identify key trends in each area rather than focusing in detail on the work of individual scholars.

\subsection{Material feminism and linguistic capital}

While radical feminists posit gender oppression as the root or fundamental form of inequality, other feminist theorists argue that women's subordination is a consequence of class oppression, which they take to be primary. This perspective is found within Marxist and socialist branches of material feminism. However, material feminist approaches range well beyond these viewpoints, while sharing a general concern with the physical conditions of gender. Material feminisms examine such diverse issues as the situation of women in the domestic sphere, both as unpaid labor and, in some contexts, as male property; the role of gender in the labor market and the class system; feminized aspects of economic production; gendered dimensions of consumption under capitalism; the linguistic commodification of gender and sexuality; and the relationship of gender and sexuality to bodies and embodied experience, biological and genetic discourses, and the natural and built 
environment (e.g., Alaimo and Hekman 2008; Hennessy and Ingraham 1997; see also Cameron 2006 on radical materialist feminism). This general perspective thus overlaps with the second-wave feminist theories already discussed, sharing with liberal feminism, for example, a commitment to workplace rights for women, and sharing with radical feminism a concern with sexual violence.

Linguistic research that engages material feminist concerns is equally broad in its scope, spanning studies of the relationship between gender, class, and variation (Eckert 1989); the ideologies and realities of women's linguistic labor in the home as mothers and wives within the traditional nuclear family (Kendall 2008; Sunderland 2006); the role of language in marketing to female and male consumers of various kinds (Benwell 2004; Lazar 2006); and the links between language and gendered embodied practices (Speer and Green 2007). In addition, examinations of gendered language in work contexts ranging from beauty salons (Toerien and Kitzinger 2007) to call centers (Cameron 2000) to factory floors (Holmes 2006) to phone sex (Hall 1995) demonstrate the enduring role of gender ideologies in the workplace as well as the growing commodification of feminized ways of speaking. (See also Holmes, Chapter 22 in this volume.) Perhaps the most widespread materialist approach within feminist linguistics is critical discourse analysis, which emerged from neo-Marxist theories of language and examines how ideological power is enacted, especially through institutional discourses such as the media, politics, and education. An explicitly feminist version of critical discourse analysis has been extremely influential (Lazar 2005; Chapter 9 in this volume); in addition, some of the most current work on sexist and homophobic language takes a critical discourse analytic standpoint (e.g., Mills 2008).

Given the vast range of theoretical, methodological, and political concerns represented by such work, it is unsurprising that material feminist approaches within linguistics have not consolidated into a single recognizable perspective as have the second-wave approaches discussed above. Rather, researchers studying one aspect of the gendered materiality of language typically do not interact closely with scholars pursuing other aspects. Yet, as I discuss further at the end of this chapter, this broad approach holds significant potential to influence the field as a whole, as well as feminism more generally, for materialist and discursive views of gender, often conceptualized as antithetical within feminist theory, are effectively combined in material feminist linguistics in all its forms.

\subsection{Critical race feminisms and linguistic intersectionalities}

While material feminisms often call attention to socioeconomic class, they do not necessarily focus on race and ethnicity, despite the fact that racialization is rooted in sociopolitical interpretations of the body and is hence a fundamentally material issue. The investigation of the intersection of race and ethnicity with class, gender, sexuality, and other dimensions of subjectivity in relation to historical and present-day workings of power is the concern of what is sometimes called multiracial feminism (Thompson 2002) and the closely related approach of 
postcolonial feminism (e.g., Mohanty, Russo, and Torres 1991). This long-standing political and intellectual movement, which goes by a number of names, has been an important counterpoint to white-dominated versions of feminism (e.g., Collins 1990; Moraga and Anzaldúa 1981; Smith 1983), and some theorists set aside the label "feminism" altogether in favor of terms that place women of color at the center of political thought and action (as seen, e.g., in Walker's 1983 concept of "womanism"). Such feminist theories may focus on the experiences of particular groups of women as well as commonalities of experience of women across politically subordinated communities; they may additionally consider the sometimes shared and sometimes divergent experiences of men of color. Some forms of multiracial feminism have been criticized as similar to cultural feminism in their focus on the cultural situatedness of gendered experience, which is often read as a form of essentialism. It is important to understand, however, that the primary concern of feminist theories of alterity based on race, ethnicity, and colonial status is not a depoliticized notion of culture; instead, such theories conceptualize the cultures of politically subordinated groups as a set of historically specific practices - including linguistic practices - that function as agentive responses to shared experiences of oppression based on inequities of race, gender, class, and nation.

Within linguistics, one of the most important contributions of multiracial feminist research has been to challenge the field's tendency to marginalize the distinctive experiences of women of color. The goal of much of this work is explicitly noncomparative, in contrast to most second-wave feminist linguistics as well as nonfeminist sociolinguistic research on gender. Multiracial feminist linguistic scholarship is committed to understanding the linguistic experiences and practices of women of color on their own terms, often with little if any comparison either to white women or to men of color. In the US context, the largest body of linguistic scholarship from this general perspective focuses on African American girls and women (Jacobs-Huey 2006; Lanehart 2009; Morgan 1999; Troutman 2001), although language and gender researchers have increasingly attended to Native Americans, Asian Americans, and Latinas as well (Ahlers 2012; Chun 2004; Mendoza-Denton 2008; Meek, Chapter 28 in this volume), as well as to whiteness as an often overlooked racialized and gendered category that merits greater scholarly scrutiny (Bucholtz 2011).

Linguistic research from a specifically postcolonial feminist standpoint remains less common. However, feminist linguistic scholarship in postcolonial settings is growing, offering the possibility of dialogue and theoretical convergence as the field continues to develop. Relevant studies include work on gender and creole languages (Escure 2001; Meyerhoff 2004), gender and multilingualism in postcolonial societies (Sadiqi 2008; Walters 1999); gendered representations of the colonized Other (Irvine 2001; Mills 1991); and clashing Western and local discourses of sexuality and gender in public health and development efforts (Clark 2006; Pigg 2001). Some of this work also makes common cause with material feminist linguistic scholarship concerned with gendered processes of globalization (McElhinny 2007; Piller and Takahashi 2006). These and other 
studies of gendered language ideologies and linguistic practices in contexts of racialized inequity around the world work to undo the long-standing pattern of erasure, marginalization, and exoticism of politically subordinated women and girls within linguistic scholarship, while demonstrating the intersectionality (Crenshaw 1991) of power-saturated social categories of race, class, nation, gender, and sexuality within language use.

\subsection{Theorizing masculinities in language}

A third general approach that critiques and expands the inclusiveness of feminist theory vis-à-vis difference-based frameworks is the set of feminist perspectives on masculinity. For many years, men's experience of gender remained largely unexplored in comparison to the extensive study of women's gendered lives. To be sure, masculinity is a key issue in second-wave feminist theories focused on cross-gender difference, but in such frameworks it is often treated as relatively fixed and monolithic and is rarely a sustained object of study. The field of masculinity studies aims to incorporate men more fully into the study of gender by taking masculinity as the starting point of inquiry rather than as the explanation for gender inequality (Connell 1995; Kimmel 1987).

Masculinity studies is sometimes seen as synonymous with and sometimes as distinct from men's studies, a field grounded in radical feminism that seeks to dismantle patriarchy through the rejection of dominant forms of masculinity (Stoltenberg 1989). Masculinity studies is also starkly different from so-called male studies, a deliberately antifeminist and academically marginal field informed by a politically conservative form of cultural and biological essentialism (Epstein 2010). Intellectually, masculinity studies is primarily concerned with investigating masculinity as a sociocultural construct that takes diverse forms. Politically, its goals are both to challenge masculinity as a warrant for male dominance and to undo the constraining effects of masculinity on men's subjectivities. Because of the racialized and politicized dimensions of masculinity, hegemonic and subaltern masculinities have also figured centrally in multicultural and postcolonial scholarship as well as in materialist approaches.

The general perspective on masculinity taken by masculinity studies has been influential in linguistic research, which has documented the variability of masculinities as they are constructed through language (Benwell, Chapter 12 in this volume; Johnson and Meinhof 1997; Kiesling 2001). In this theoretical approach, what unifies diverse forms of masculinity is power, which is conceptualized as fundamental to how masculinity works. More recent linguistic scholarship complicates the link between masculinity and power, noting in particular the growing ideological destabilization of hegemonic forms of masculinity and the constant identity work required to sustain this construct (Bucholtz and Lopez 2011; Korobov 2009; Milani 2011; Chapter 13 in this volume; Sunderland 2000). Such research points to the insecure status of masculine hegemony at this cultural moment as well as the critical role of language in both delinking and relinking masculinity and power. As discussed further below, following recent trends in gender theory (e.g., Halberstam 1998) scholars are also beginning to conceptually separate masculinity 
from men by examining the role of masculinity among women as well as those with fluid or nonbinary gender identifications.

All of the critical approaches discussed above open up feminist theory - and feminist linguistics - to the possibility of more complex conceptualizations of gender than a simple matter of women and men. The final set of feminist frameworks considered in this chapter addresses this issue from a variety of perspectives.

\section{Queering Feminism: From Gender to Sexuality and Back Again}

Whereas both second-wave feminist scholarship and the critical forms of feminism that respond to it often take gender as a given, other feminist theories have sought to interrogate gender itself, frequently by examining the close relationship between gender and sexuality. Sexuality in these theoretical approaches is generally understood both as a form of identity (especially with respect to sexual orientation) and as a set of embodied practices (especially with respect to sexual activity) (Bucholtz and Hall 2004). Such feminist theories come from a broadly queer perspective in that they challenge binary and normative categories based on gender, sexuality, or both. Of course, many of the theories discussed above contribute to this endeavor as well. For example, the critical writings of lesbians of color foreground sexual identity alongside race and ethnicity as a crucial component of intersectionality (e.g., Anzaldúa 1987; Lorde 1984; Moraga 1983), and masculinity studies shares some important conceptual connections with feminist theories of gender and transgender (e.g., Connell 1987; Halberstam 1998). At the same time, there are considerable disagreements within and among all of these overarching approaches.

\subsection{Theorizing lesbian, gay, and bisexual identities in language}

Like many of the theoretical perspectives on gender discussed above, the focus on lesbian, gay, bisexual, and transgender (LGBT) issues began as a series of political movements and developed a scholarly arm as LGBT research began to gain ground in academia. Despite the shared discourse of rights and inequality found in both liberal feminism and the gay liberation movement, the relationship between feminism and the gay rights movement was historically fraught with tension (see, e.g., Frye 1983). More intimate links existed between radical feminism and lesbian feminism (e.g., Hoagland and Penelope 1992), and between New Age-influenced versions of men's studies and certain gay subcultures (see discussion in Barrett, in press). More recently, feminist and LGBT efforts have become more closely allied in political coalitions as well as in scholarly discourse, the latter in part owing to their shared reliance on Butler's gender theory, as discussed below. These two areas continue to develop separately as well as in tandem.

In all its manifestations, LGBT studies aims both to challenge the sociopolitical marginalization of those who do not conform to heteronormative regimes of 
sexuality and gender and to investigate the experiences and practices associated with these identities (Abelove, Barale, and Halperin 1993). Such work sometimes focuses on individual categories of non-normative sexuality and/or gender and sometimes on two or more of these together. This political and intellectual coalition, however, has been uneasy at times. Despite ongoing efforts to be maximally inclusive of the identities represented, as reflected by its increasingly unwieldy acronym, within this approach bisexual and transgender identities in particular have often remained marginalized (but see Thorne 2013 as well as the discussion below for new feminist linguistic research on these topics).

Linguistic approaches to LGBT issues generally investigate three types of questions: linguistic aspects of the social and political struggle of LGBT groups and individuals (VanderStouwe 2013), the linguistic practices of particular LGBT-identified groups (Jones 2012; Leap 1996; R. Queen 2005), and discursive representations of LGBT identities by both ingroup and outgroup members (Baker 2005; Koller 2008). Although some of the earliest work from this perspective has come in for attack for what has been characterized as an essentialized understanding of sexual identity (Kulick 2000; Chapter 3 in this volume), the vast majority of recent research is grounded in contemporary theories of gender and sexuality that view identities as highly variable sociocultural constructs produced in large part through language. And even the earlier scholarship, which sometimes elides distinctions between groups in a strategic essentialist move to advance the political goal of social equality, resembles radical cultural feminism in its efforts to validate the language of sexual (and sometimes, gender) minorities (cf. McElhinny 1996).

\subsection{Sex-positive feminism and the language of sexual practice}

In addition to examining sexuality as identity, particularly with regard to sexual minorities, feminist perspectives have also been taken toward sexuality as practice. This undertaking has both activist and academic dimensions, as sex workers, sex educators, and pro-sex advocates have made common cause with scholars around the issue of women's sexual pleasure (e.g., Califia 1994; C. Queen 1997; Vance 1984). This topic has long been fraught with controversy within feminist politics, due to the early radical feminist theorizing of heterosexual sex and pornography as inherently violent and oppressive, a viewpoint that has also often been extended to lesbian pornography and to lesbian sexual activities that explore and eroticize ritual dominance and submission (including bondage/discipline and sadism/masochism, often referred to by the acronym BDSM). By legitimating women's sexual pleasure in all its forms, including these politically and culturally taboo sexual practices, sex-positive feminists emphasize that acknowledging the diversity of sexual experiences and desires for all sexual actors is not only consistent with but central to feminist goals. Sex-positive feminism has also produced an extensive body of feminist erotica (e.g., Bright 1988), which linguistically 
produces women as sexual subjects with complex desires, in contrast to traditional representations in bodice-ripper supermarket romances aimed at heterosexual women (Talbot 1997).

As the example of erotica suggests, language is an important dimension of sexual activities and practices. Yet, as in other arenas of gender and sexuality that centrally involve embodiment and physicality, material feminist concerns have often been privileged in feminist thinking about these matters to the exclusion of linguistic issues; thus, feminist linguistic research is well positioned to unify materialist and discursive perspectives. Indeed, scholars of language, gender, and sexuality have used linguistic insights to examine a variety of sexual practices (Harvey and Shalom 1997), from the use of safewords in BDSM (Cameron and Kulick 2003) to the linguistic management of physicality in gay men's online sexual encounters (Jones 2005; 2008) to discussions of sexual knowledge among teenage girls (Skapoulli 2009). Despite the considerable ethical and practical challenges in documenting language use in sexual contexts, such work, when responsibly conducted, is invaluable for shedding light on the pivotal role of language in sexual situations.

\subsection{Poststructuralist feminism and the linguistic challenge to gender}

The final theoretical framework considered in this chapter, which sometimes goes by the label poststructuralist (or postmodern) feminism (cf. Nicholson 1990), scrutinizes binary models of sex, gender, and sexuality for what they reveal about the social organization of these categories and how they are challenged by complex identities and practices, including not only lesbian, gay, and bisexual identities, but also transgender, transsexual, intersex, genderqueer, and other identities that are increasingly moving to the center of feminist theory. This general perspective takes as its starting point Judith Butler's (1990) revolutionary notion of performativity, or the idea that gender and sexuality are brought into being through the repeated discursive enactment of cultural norms. Crucial to this concept is the possibility of disrupting the normative alignment of sex assignment, gender identity, and sexual identity through such practices as drag performances, in which gay men appropriate femininity in order to challenge heteronormativity. For this reason, queer theory, especially in its more feminist forms, draws heavily on Butler's work (Marinucci 2010). Approaches that interrogate gender also encompass the study of everyday rather than staged practices that decouple gender from assigned sex and sexuality, as with some transgender and transsexual identities, or practices that refuse gender categorization altogether, as with some trans and intersex identities (e.g., Bornstein 1994; Kessler 1998; Stryker and Whittle 2006).

Performativity derives from a concept within the philosophy of language, the performative speech act (Austin 1962), or speech that changes the world through language. Performativity is therefore a fundamentally linguistic-or, more generally, semiotic - act. Not surprisingly, then, Butler's theory precipitated an outpouring of feminist linguistic research examining the linguistic resources that 
bring gender into being (e.g., Bergvall, Bing, and Freed 1996; Bucholtz, Liang, and Sutton 1999; Hall and Bucholtz 1995; McIlvenny 2002), as well as the development of an explicitly poststructuralist feminist discourse analytic framework (Baxter 2003). Within feminist linguistics, a queer perspective has also been engaged by a number of researchers, beginning with the foundation of queer linguistics (Livia and Hall 1997) and continuing with the work of a new generation of scholars (e.g., Milani, Chapter 13 in this volume; Zimman, Davis, and Raclaw, in press). These authors aim not simply to dismantle binaries but to examine their productive potential for nonhegemonic gender and sexual subjectivities (Zimman and Hall 2010), not only via investigations of the sorts of drag performances that inspired Butler (e.g., Barrett 1999) but also through an ongoing focus on gender categories around the world that challenge Western binaries (e.g., Besnier 2003; Boellstorff 2004; Borba and Ostermann 2007; Gaudio 2009; Hall 2005; Hall and O'Donovan 1996). This latter body of research intersects with postcolonial feminism in its attention to how non-normative gender identities are mapped onto binaries like modern/traditional. Recently, feminist linguistic scholarship has likewise begun to examine how categories of gender, sex, and sexuality are put to work in more-than-binary identities in the late modern West (e.g., Speer and Green 2007; Speer and Parsons 2006; Zimman 2009).

Linguistic research from a queer perspective thus ranges from a concern with sexual alterity to the linguistic dimensions of sexual activity to the nuanced configurations of gender, sex, and sexuality that transgender and other nonbinary identities make possible. And once again, in its focus on these issues as simultaneously discursive and embodied, such research offers a much needed bridge between discourse-centered poststructuralist perspectives and material feminist concerns with the body.

\section{A New Linguistic Turn?}

As I hope to have demonstrated in this brief survey, feminist linguistics is richly informed by feminist theory. And in the past 20 years there has been a noticeable trend toward embracing theory more explicitly than in previous decades particularly the version of feminist theory articulated by Butler (1990). Such a turn of events is no accident, for Butler was instrumental in popularizing the so-called linguistic turn in Anglo-American feminist theory (e.g., Fraser 1995), parallel to similar developments in French feminism and in critical theory and philosophy more generally. It is no wonder, then, that researchers who had long recognized the intimate connection between language, gender, and sexuality would welcome this newfound feminist interest in the workings of language. Although the linguistic turn did not result in a raised profile for language, gender, and sexuality studies among feminists in other fields, it did lead Butler's work to enter the theoretical canon of feminist linguistics, where it has frequently been used with insight and sophistication. Yet there is much more to the field of language, gender, and sexuality than can be captured by any single theory, no matter how brilliant and groundbreaking. While Butler's work has provided one of the most productive 
theories the field has encountered, it is important to expand recognition of the many theoretical perspectives that inform feminist linguistic work, both explicitly and implicitly.

Moreover, feminist linguistics is uniquely positioned to play a leading role in shaping new developments in feminist theory, and particularly in forging a rapprochement between discursive and materialist perspectives, which have too often been at odds in feminist theoretical debates (e.g., Ahmed 2008; Barad 2003). Feminist linguistics bridges this artificial divide, thanks in part to the growing use of new methodologies, especially video analysis, that require recognition of the fundamental materiality of language. But more generally, the field has long been concerned with the simultaneously discursive and material character of gender and sexuality, as seen in a wide range of phenomena, including embodied communicative action that indexes gendered or sexual subjectivities; linguistic and bodily engagements with the environment and technology; the gendered and sexualized voice; the global commodification of gendered language; language in sexual practice; and the material effects of discourses of gender and sexuality (cf. Shankar and Cavanaugh 2012). One example of what a linguistically informed feminist theory might look like is Mel Chen's (2012) rich and highly innovative work bringing cognitive linguistics into dialogue with queer theory, animal studies, and understandings of the body. But of course many other sorts of theoretical engagements are both possible and necessary. It may be time, then, for a new linguistic turn in feminist theory, one that is equally concerned with discourse and materiality as consequential for the workings of gender and sexuality.

\section{Conclusion}

In this chapter I have sought both to reaffirm and to revisit the feminist foundations of language, gender, and sexuality studies, at least as I understand them from my vantage point as a US-trained scholar who came of age as a feminist and a linguist in the 1990s. As I have discussed, the theoretical roots of feminist linguistics lie in the difference-based theories that emerged during feminism's second wave, which placed women's concerns at the center of scholarly analysis for the first time in history. The field has gone on to expand its remit from its original focus on white straight middle-class women to a more inclusive perspective, thanks to the influence of critical feminisms concerned with materiality, race and colonialism, and masculinity. And in response to feminist interrogations of the relationship of gender to sexuality on the one hand and to sex on the other under the general banner of queer feminism, growing numbers of language-oriented scholars address questions of sexual identity and practice as well as of gender and sexual alterity. I have also argued for the continuing value of poststructuralist feminism even as the field moves toward an approach to discourse grounded in the materialities of the body, the natural and built environment, and the global political economy.

A continuing engagement with feminist theory will lead feminist linguistics in many fruitful directions by creatively combining insights from multiple perspectives, by introducing new theoretical approaches, and by tying scholarship more 
closely to activism and advocacy work. Throughout this process, feminist linguists must also develop our own endogenous theoretical perspectives in dialogue with feminists in other fields.

\section{Acknowledgments}

My deepest thanks to the editors of this volume for their patience and forbearance during the slow development of this chapter. Some of the material in these pages was presented, in a rather different form, to the 7th International Gender and Language Association Conference in São Leopoldo, Brazil, in 2012; thanks are due to audience members for their feedback. The ideas presented here have also benefited from the invaluable comments of an anonymous reviewer; from the insights of my graduate and undergraduate students in language, gender, and sexuality; and from ongoing discussions of feminist theory with Kira Hall. I owe special thanks to Kira for her careful and astute reading of an earlier version of the chapter. I alone am responsible for any problems of representation, interpretation, or omission in these pages.

\section{NOTES}

1 Henceforth, the term "feminist linguistics" is used interchangeably with "language, gender, and sexuality," but it is important to recognize that many of the researchers within the field are affiliated with disciplines other than linguistics.

2 Although I argue here that Lakoff's earliest work is generally aligned with liberal feminism, her later writings include elements of radical feminism as well. See McElhinny (2004) for Lakoff's radical feminist orientation beginning with Language and Woman's Place, and Cameron $(1990,23)$ for a discussion of Lakoff's concern with male dominance.

3 It is worth noting that Tannen earned her PhD under Lakoff's supervision; Lakoff was also my own graduate adviser.

4 I focus here on Ehrlich's contributions to a radical feminist critique of gendered violence, but her work is also informed by material feminism (Ehrlich 2004) and poststructuralist feminism (Ehrlich 2007), among others.

\section{REFERENCES}

Abelove, Henry, Michèle Aina Barale, and David M. Halperin, eds. 1993. The Lesbian and Gay Studies Reader. New York: Routledge.

Ahlers, Jocelyn C. 2012. "Language Revitalization and the (Re)Constituting of Gender: Silence and Women in Native
California Language Revitalization." Gender and Language, 6(2): 309-337.

Ahmed, Sara. 2008. "Imaginary Prohibitions: Some Preliminary Remarks on the Founding Gestures of the 'New Materialism.'" European Journal of Women's Studies, 15(1): 23-39. 
Alaimo, Stacy, and Susan Hekman, eds. 2008. Material Feminisms. Bloomington: Indiana University Press.

Anzaldúa, Gloria. 1987. Borderlands/La Frontera: The New Mestiza. San Francisco: Spinsters/Aunt Lute.

Austin, J. L. 1962. How to Do Things with Words. Cambridge, MA: Harvard University Press.

Baker, Paul. 2005. Public Discourses of Gay Men. London: Routledge.

Barad, Karen. 2003. "Posthumanist Performativity: Toward an Understanding of How Matter Comes to Matter." Signs, 28(3): 801-831.

Barrett, Rusty. 1999. “Indexing Polyphonous Identity in the Speech of African American Drag Queens." In Mary Bucholtz, A. C. Liang, and Laurel A. Sutton (eds.), Reinventing Identities: The Gendered Self in Discourse, 313-331. New York: Oxford University Press.

Barrett, Rusty. In press. From Drag Queens to Leathermen: Language, Gender, and Gay Male Subcultures. New York: Oxford University Press.

Baxter, Judith. 2003. Positioning Gender in Discourse: A Feminist Methodology. Basingstoke: Palgrave Macmillan.

Baxter, Judith. 2010. The Language of Female Leadership. Basingstoke: Palgrave Macmillan.

Beasley, Chris. 1999. What Is Feminism? An Introduction to Feminist Theory. Thousand Oaks, CA: Sage.

Belenky, Mary, Blythe McVicker Clinchy, Nancy Rule Goldberger, and Jill Mattuck Tarule. 1986. Women's Ways of Knowing. New York: Basic Books.

Benwell, Bethan. 2004. "Ironic Discourse: Evasive Masculinity in Men's Lifestyle Magazines." Men and Masculinities, 7(1): 3-21.

Bergvall, Victoria L., Janet M. Bing, and Alice F. Freed, eds. 1996. Rethinking Language and Gender Research: Theory and Practice. London: Longman.

Besnier, Niko. 2003. "Crossing Gender, Mixing Languages: The Linguistic Construction of Transgenderism in Tonga." In Janet Holmes and Miriam Meyerhoff (eds.), The Handbook of Language and Gender, 279-301. Oxford: Blackwell.

Boellstorff, Tom. 2004. "Gay Language in Indonesia." Journal of Linguistic Anthropology, 14(2): 248-268.

Borba, Rodrigo, and Ana C. Ostermann. 2007. “Do Bodies Matter? Travestis' Embodment of (Trans)Gender Identity through the Manipulation of the Brazilian Portuguese Grammatical Gender System." Gender and Language, 1(1): 131-147.

Bornstein, Kate. 1994. On Men, Women, and the Rest of Us. New York: Routledge.

Bright, Susie, ed. 1988. Herotica: A Collection of Women's Erotic Fiction. San Francisco: Down There Press.

Brownmiller, Susan. 1975. Against Our Will: Men, Women, and Rape. New York: Simon \& Schuster.

Bucholtz, Mary. 1999. "Review of Women Talk by Jennifer Coates." American Speech, 74(4): 433-436.

Bucholtz, Mary. 2004. "Changing Places: Language and Woman's Place in Context." In Robin Tolmach Lakoff, Language and Woman's Place: Text and Commentaries, rev. and expanded edn, ed. Mary Bucholtz, 121-128. New York: Oxford University Press.

Bucholtz, Mary. 2011. White Kids: Language, Race, and Styles of Youth Identity. Cambridge: Cambridge University Press.

Bucholtz, Mary, and Kira Hall. 1995. "Introduction: Twenty Years after Language and Woman's Place." In Kira Hall and Mary Bucholtz (eds.), Gender Articulated: Language and the Socially Constructed Self, 1-22. New York: Routledge.

Bucholtz, Mary, and Kira Hall. 2004.

"Theorizing Identity in Language and Sexuality Research." Language in Society, 33(4): 501-547.

Bucholtz, Mary, A. C. Liang, and Laurel A. Sutton, eds. 1999. Reinventing Identities: The Gendered Self in Discourse. New York: Oxford University Press.

Bucholtz, Mary, and Qiuana Lopez. 2011. "Performing Blackness, Forming Whiteness: Linguistic Minstrelsy in Hollywood Film." Journal of Sociolinguistics, 15(5): 680-706. 
Butler, Judith. 1990. Gender Trouble: Feminism and the Subversion of Identity. New York: Routledge.

Califia, Pat. 1994. Public Sex: The Culture of Radical Sex. San Francisco: Cleis Press.

Cameron, Deborah. 1985. Feminism and Linguistic Theory. Basingstoke: Macmillan.

Cameron, Deborah, ed. 1990. The Feminist Critique of Language. London: Routledge.

Cameron, Deborah. 1995. "Rethinking Language and Gender Studies: Some Issues for the 1990s." In Sara Mills (ed.), Language and Gender: Interdisciplinary Perspectives, 31-44. Harlow: Longman.

Cameron, Deborah. 2000. "Styling the Worker: Gender and the Commodification of Language in the Globalized Service Economy." Journal of Sociolinguistics, 4(3): 323-347.

Cameron, Deborah. 2006. On Language and Sexual Politics. London: Routledge.

Cameron, Deborah, and Don Kulick. 2003. Language and Sexuality. Cambridge: Cambridge University Press.

Chen, Mel Y. 2012. Animacies: Biopolitics, Racial Mattering, and Queer Affect. Durham, NC: Duke University Press.

Chun, Elaine W. 2004. "Ideologies of Legitimate Mockery: Margaret Cho's Revoicings of Mock Asian." Pragmatics, 14(2-3): 263-289.

Clark, Jude. 2006. "The Role of Language and Gender in the Naming and Framing of HIV / AIDS in the South African Context." Southern African Linguistics and Applied Language Studies, 24(4): 461-471.

Coates, Jennifer. 1996. Women Talk. Oxford: Blackwell.

Collins, Patricia Hill. 1990. Black Feminist Thought: Knowledge, Consciousness, and the Politics of Empowerment. Boston: Unwin Hyman.

Connell, R. W. 1987. Gender and Power. Stanford: Stanford University Press.

Connell, R. W. 1995. Masculinities. Berkeley: University of California Press.

Crenshaw, Kimberlé W. 1991. "Mapping the Margins: Intersectionality, Identity Politics, and Violence against Women of Color." Stanford Law Review, 43(6): 1241-1299.

Daly, Mary. 1978. Gyn/Ecology: The Metaethics of Radical Feminism. Boston: Beacon.
Daly, Mary, and Jane Caputi. 1987. Websters' First New Intergalactic Wickedary of the English Language. Boston: Beacon.

Davis, Hayley. 1996. "Review Article: Theorizing Women's and Men's Language." Language and Communication, 16(1): 71-79.

Davis, Hayley. 1997. "Gender, Discourse and Gender and Discourse." Language and Communication, 17(4): 353-357.

Dworkin, Andrea. 1974. Woman Hating: A Radical Look at Sexuality. New York: Dutton.

Dworkin, Andrea. 1987. Intercourse. New York: Free Press.

Eckert, Penelope. 1989. "The Whole Woman: Sex and Gender Differences in Variation." Language Variation and Change, 1: 245-267.

Ehrlich, Susan. 2001. Representing Rape: Language and Sexual Consent. New York: Routledge.

Ehrlich, Susan. 2004. "Linguistic Discrimination and Violence against Women: Discursive Practices and Material Effects." In Robin Tolmach Lakoff, Language and Woman's Place: Text and Commentaries, rev. and expanded edn, ed. Mary Bucholtz, 223-228. New York: Oxford University Press.

Ehrlich, Susan. 2007. "Legal Discourse and the Cultural Intelligibility of Gendered Meanings." Journal of Sociolinguistics, 11(4): $452-477$.

Epstein, Jennifer. 2010. "Male Studies vs. Men's Studies." Inside Higher Ed (April 8). At http:/ / www.insidehighered .com/news/2010/04/08/males, accessed October 8, 2013.

Escure, Geneviève. 2001. "Belizean Creole: Gender, Creole, and the Role of Women in Language Change." In Marlis Hellinger and Hadumod Bussmann (eds.), Gender across Languages: The Linguistic Representation of Women and Men, vol. 1, 53-84. Amsterdam: Benjamins.

Estrich, Susan. 1987. Real Rape. Cambridge, MA: Harvard University Press.

Fishman, Pamela. 1983. "Interaction: The Work Women Do." In Barrie Thorne, Cheris Kramarae, and Nancy Henley (eds.), Language, Gender, and Society, 89-101. Cambridge, MA: Newbury House. 
Frank, Francine Wattman, and Paula A. Treichler. 1989. Language, Gender, and Professional Writing. New York: Modern Language Association.

Fraser, Nancy. 1995. "Pragmatism, Feminism, and the Linguistic Turn." In Seyla Benhabib, Judith Butler, Drucilla Cornell, and Nancy Fraser (eds.), Feminist Contentions: A Philosophical Exchange, 157-171. New York: Routledge.

Freed, Alice. 1992. “We Understand Perfectly: A Critique of Tannen's View of Cross-Sex Communication." In Kira Hall, Mary Bucholtz, and Birch Moonwomon (eds.), Locating Power: Proceedings of the Second Berkeley Women and Language Conference, vol. 2, 144-152. Berkeley: Berkeley Women and Language Group.

Friedan, Betty. 1963. The Feminine Mystique. New York: Norton.

Frye, Marilyn. 1983. The Politics of Reality: Essays in Feminist Theory. Freedom, CA: Crossing Press.

Gardner, Carol Brooks. 1980. “Passing By: Street Remarks, Address Rights, and the Urban Female." Sociological Inquiry, 50(3-4): 328-356.

Gaudio, Rudolf Pell. 2009. Allah Made Us: Sexual Outlaws in an Islamic African City. Oxford: Blackwell.

Gilligan, Carol. 1982. In a Different Voice: Psychological Theory and Women's Development. Cambridge, MA: Harvard University Press.

Goodwin, Marjorie Harness. 2006. The Hidden Life of Girls: Games of Stance, Status, and Exclusion. Malden, MA: Blackwell.

Halberstam, Judith. 1998. Female Masculinity. Durham, NC: Duke University Press.

Hall, Kira. 1995. “Lip Service on the Fantasy Lines." In Kira Hall and Mary Bucholtz (eds.), Gender Articulated: Language and the Socially Constructed Self, 183-216. New York: Routledge.

Hall, Kira. 2005. "Intertextual Sexuality: Parodies of Class, Identity, and Desire in Delhi." Journal of Linguistic Anthropology, 15(1): 125-144.

Hall, Kira, and Mary Bucholtz, eds. 1995. Gender Articulated: Language and the Socially Constructed Self. New York: Routledge.
Hall, Kira, and Veronica O'Donovan. 1996. "Shifting Gender Positions among Hindi-Speaking Hijras." In Victoria L. Bergvall, Janet M. Bing, and Alice F. Freed (eds.), Rethinking Language and Gender Research: Theory and Practice, 228-266. London: Longman.

Harvey, Keith, and Celia Shalom, eds. 1997. Language and Desire: Encoding Sex, Romance and Intimacy. London: Routledge.

Hass, Mary. 2000. "The Style of the Speaking Subject: Irigaray's Empirical Studies of Language Production." Hypatia, 15(1): 64-89.

Hennessy, Rosemary, and Chrys Ingraham, eds. 1997. Materialist Feminism: A Reader in Class, Difference, and Women's Lives. New York: Routledge.

Herring, Susan C. 1999. "The Rhetorical Dynamics of Gender Harassment On-line." Information Society, 15(3): 151-167.

Hoagland, Sarah Lucia, and Julia Penelope, eds. 1992. For Lesbians Only: A Separatist Anthology. London: Onlywomen Press.

Holmes, Janet. 1993. "New Zealand Women Are Good to Talk to: An Analysis of Politeness Strategies in Interaction." Journal of Pragmatics, 20(2): 91-116.

Holmes, Janet. 2006. Gendered Talk at Work: Constructing Gender Identity through Workplace Discourse. Oxford: Blackwell.

Houvouras, Shannon, and J. Scott Carter. 2008. "The F Word: College Students' Definitions of a Feminist." Sociological Forum, 23(2): 234-256.

Irvine, Judith T. 2001. “The Family Romance of Colonial Linguistics: Gender and Family in Nineteenth-Century Representations of African Languages." In Susan Gal and Kathryn A. Woolard (eds.), Languages and Publics: The Making of Authority, 13-29. Manchester: St. Jerome.

Jackson, Stevi, and Jackie Jones, eds. 1998. Contemporary Feminist Theories. Edinburgh: Edinburgh University Press.

Jacobs-Huey, Lanita. 2006. From the Kitchen to the Parlor: Language and Becoming in African American Women's Hair Care. New York: Oxford University Press.

Johnson, Sally, and Ulrike Meinhof, eds. 1997. Language and Masculinity. Oxford: Blackwell. 
Jones, Lucy. 2012. Dyke/Girl: Language and Identities in a Lesbian Group. Basingstoke: Palgrave Macmillan.

Jones, Rodney H. 2005. "'You Show Me Yours, I'll Show You Mine': The Negotiation of Shifts from Textual to Visual Modes in Computer-Mediated Interaction among Gay Men." Visual Communication, 4(1): 69-92.

Jones, Rodney H. 2008. "The Role of Text in Televideo Cybersex." Text and Talk, 28(4): 453-473.

Kendall, Shari. 2008. "The Balancing Act: Framing Gendered Parental Identities at Dinnertime." Language in Society, 37(4): 539-568.

Kessler, Suzanne J. 1998. Lessons from the Intersexed. New Brunswick, NJ: Rutgers University Press.

Kiesling, Scott Fabius. 2001. "'Now I Gotta Watch What I Say': Shifting Constructions of Masculinity in Discourse." Journal of Linguistic Anthropology, 11(2): 250-273.

Kimmel, Michael. 1987. Changing Men: New Directions in the Study of Men and Masculinity. Newbury Park, CA: Sage.

Kissling, Elizabeth Arveda. 1991. "Street Harassment: The Language of Sexual Terrorism." Discourse and Society, 2(4): 451-460.

Kitzinger, Celia, and Hannah Frith 1999. "Just Say No? The Use of Conversation Analysis in Developing a Feminist Perspective on Sexual Refusal." Discourse and Society, 10(3): 293-316.

Koller, Veronika. 2008. Lesbian Discourses: Images of a Community. London: Routledge.

Korobov, Neill. 2009. “'He's Got No Game': Young Men's Stories about Failed Romantic and Sexual Experiences." Journal of Gender Studies, 18(2): 99-114.

Kulick, Don. 2000. "Gay and Lesbian Language." Annual Review of Anthropology, 29: 243-285.

Lakoff, Robin Tolmach. 2004 [1975]. Language and Woman's Place: Text and Commentaries, rev. and expanded edn, ed. Mary Bucholtz. New York: Oxford University Press. (First published New York: Harper \& Row.)
Lanehart, Sonja L., ed. 2009. African American Women's Language: Discourse, Education, and Identity. Newcastle upon Tyne: Cambridge Scholars Publishing.

Lazar, Michelle M., ed. 2005. Feminist Critical Discourse Analysis: Gender, Power and Ideology in Discourse. Basingstoke: Palgrave Macmillan.

Lazar, Michelle M. 2006. "'Discover the Power of Femininity!' Analyzing Global 'Power Femininity' in Local Advertising." Feminist Media Studies, 6(4): 505-517.

Leap, William L. 1996. Word's Out: Gay Men's English. Minneapolis: University of Minnesota Press.

Livia, Anna. 2000. Pronoun Envy: Literary Uses of Linguistic Gender. Oxford: Oxford University Press.

Livia, Anna, and Kira Hall, eds. 1997. Queerly Phrased: Language, Gender, and Sexuality. New York: Oxford University Press.

Lorde, Audre. 1984. Sister Outsider: Essays and Speeches. Berkeley, CA: Crossing Press.

Maltz, Daniel N., and Ruth A. Borker. 1982. "A Cultural Approach to Male-Female Miscommunication." In John J. Gumperz (ed.), Language and Social Identity, 196-216. Cambridge: Cambridge University Press.

Marinucci, Mimi. 2010. Feminism Is Queer: The Intimate Connection between Queer and Feminist Theory. London: Zed.

Marks, Elaine, and Isabelle de Courtivron. 1980. New French Feminisms: An Anthology. New York: Schocken.

McElhinny, Bonnie. 1996. "Strategic Essentialism in Sociolinguistic Studies of Gender." In Natasha Warner, Jocelyn Ahlers, Leela Bilmes, Monica Oliver, Suzanne Wertheim, and Melinda Chen (eds.), Gender and Belief Systems: Proceedings of the Fourth Berkeley Women and Language Conference, 469-480. Berkeley: Berkeley Women and Language Group.

McElhinny, Bonnie. 2004. "'Radical Feminist' as Label, Libel, and Laudatory Chant: The Politics of Theoretical Taxonomies in Feminist Linguistics." In Robin Tolmach Lakoff, Language and Woman's Place: Text and Commentaries, rev. and expanded edn, 
ed. Mary Bucholtz, 129-135. New York: Oxford University Press.

McElhinny, Bonnie, ed. 2007. Words, Worlds, and Material Girls: Language, Gender, Globalized Economy. Berlin: Mouton de Gruyter.

Mcllvenny, Paul, ed. 2002. Talking Gender and Sexuality. Amsterdam: Benjamins.

Mendoza-Denton, Norma. 2008. Homegirls: Language and Cultural Practice among Latina Youth Gangs. Oxford: Blackwell.

Meyerhoff, Miriam. 2004. "Attitudes to Gender and Creoles: A Case Study on Mokes and Titas." Te Reo, 47: 63-82.

Milani, Tommaso M., ed. 2011. "Re-casting Language and Masculinities" (special issue). Gender and Language, 5(2).

Miller, Casey, and Kate Swift. 1977. Words and Women. New York: Knopf.

Mills, Sara. 1991. Discourses of Difference: Analysis of Women's Travel Writing and Colonialism. London: Routledge.

Mills, Sara. 2008. Language and Sexism. Cambridge: Cambridge University Press.

Mohanty, Chandra Talpade, Ann Russo, and Lourdes Torres, eds. 1991. Third World Women and the Politics of Feminism. Bloomington: Indiana University Press.

Moraga, Cherríe. 1983. Loving in the War Years: Lo que Nunca Pasó por sus Labios. Boston: South End Press.

Moraga, Cherríe, and Gloria Anzaldúa, eds. 1981. This Bridge Called My Back: Writings by Radical Women of Color. New York: Kitchen Table: Women of Color Press.

Morgan, Marcyliena. 1999. "No Woman No Cry: Claiming African American Women's Place." In Mary Bucholtz, A. C. Liang, and Laurel A. Sutton (eds.), Reinventing Identities: The Gendered Self in Discourse, 27-45. New York: Oxford University Press.

Nicholson, Linda J., ed. 1990.

Feminism/Postmodernism. New York: Routledge.

Ochs, Elinor, and Carolyn Taylor. 1995. "The 'Father Knows Best' Dynamic in Dinnertime Narratives." In Kira Hall and Mary Bucholtz (eds.), Gender Articulated: Language and the Socially Constructed Self, 97-120. New York: Routledge.
Pauwels, Anne. 1998. Women Changing Language. London: Longman.

Penelope, Julia. 1990. Speaking Freely: Unlearning the Lies of the Fathers' Tongues. New York: Pergamon Press.

Pigg, Stacy Leigh. 2001. "Languages of Sex and AIDS in Nepal: Notes on the Social Production of Commensurability." Cultural Anthropology, 16(4): 481-541.

Piller, Ingrid, and Kimie Takahashi. 2006. “A Passion for English: Desire and the Language Market." In Aneta Pavlenko (ed.), Bilingual Minds: Emotional Experience, Expression and Representation, 59-83. Clevedon: Multilingual Matters.

Queen, Carol. 1997. Real Live Nude Girl: Chronicles of Sex-Positive Culture. San Francisco: Cleis Press.

Queen, Robin. 2005. “'How Many Lesbians Does it Take...' : Jokes, Teasing, and the Negotiation of Stereotypes about Lesbians." Journal of Linguistic Anthropology, 15(2): 239-257.

Ragan, Sandra L., Dianne G. Bystrom, Lynda Lee Kaid, and Christina S. Beck, eds. 1996. The Lynching of Language: Gender, Politics, and Power in the Hill-Thomas Hearings. Urbana: University of Illinois Press.

Sadiqi, Fatima. 2008. "Language and Gender in Moroccan Urban Areas." International Journal of the Sociology of Language, 190: 145-165.

Shankar, Shalini, and Jillian R. Cavanaugh. 2012. "Language and Materiality in Global Capitalism." Annual Review of Anthropology, 41: 355-369.

Simmons, Rachel. 2002. Odd Girl Out: The Hidden Culture of Aggression in Girls. San Diego: Harcourt.

Skapoulli, Elena. 2009. "Transforming the Label of 'Whore': Teenage Girls' Negotiation of Local and Global Gender Ideologies in Cyprus." Pragmatics, 19(1): 85-101.

Smith, Barbara, ed. 1983. Home Girls: A Black Feminist Anthology. New York: Kitchen Table: Women of Color Press.

Speer, Susan A., and Richard Green. 2007. "On Passing: The Interactional Organization of Appearance Attributions 
in the Psychiatric Assessment of Transsexual Patients." In Victoria Clark and Elizabeth Peel (eds.), Out in Psychology: Lesbian, Gay, Bisexual, Trans and Queer Perspectives, 335-368. Chichester: Wiley.

Speer, Susan A., and Ceri Parsons. 2006. "Gatekeeping Gender: Some Features of the Use of Hypothetical Questions in the Psychiatric Assessment of Transsexual Patients." Discourse and Society, 18(1): 785-812.

Spender, Dale. 1985. Man Made Language, 2nd edn. London: Routledge \& Kegan Paul.

Stoltenberg, John. 1989. Refusing to Be a Man: Essays on Sex and Justice. Portland, OR: Breitenbush Books.

Stryker, Susan, and Stephen Whittle, eds. 2006. The Transgender Studies Reader. New York: Routledge.

Sunderland, Jane. 2000. “Baby Entertainer, Bumbling Assistant and Line Manager: Discourses of Fatherhood in Parentcraft Texts." Discourse and Society, 11(2): 249-274.

Sunderland, Jane. 2006. "'Parenting' or 'Mothering'? The Case of Modern Childcare Magazines." Discourse and Society, 17(4): 503-528.

Talbot, Mary. 1997. “'An Explosion Deep Inside Her': Women's Desire and Popular Romance Fiction." In Keith Harvey and Celia Shalom (eds.), Language and Desire: Encoding Sex, Romance and Intimacy, 222-244. London: Routledge.

Tannen, Deborah. 1990. You Just Don't Understand: Women and Men in Conversation. New York: William Morrow.

Tannen, Deborah. 1994. Gender and Discourse. New York: Oxford University Press.

Thompson, Becky. 2002. "Multiracial Feminism: Recasting the Chronology of Second Wave Feminism." Feminist Studies, 28(2): 337-360.

Thorne, Lisa. 2013. “'But I'm Attracted to Women': Sexuality and Sexual Identity Performance in Interactional Discourse among Bisexual Students." Journal of Language and Sexuality, 2(1): 70-100.
Toerien, Merran, and Celia Kitzinger. 2007. "Emotional Labour in Action: Navigating Multiple Involvements in the Beauty Salon." Sociology, 41(4): 645-662.

Tong, Rosemarie. 2009. Feminist Thought: A More Comprehensive Introduction, 3rd edn. Boulder, CO: Westview Press.

Trinch, Shonna. 2003. Latinas' Narratives of Domestic Abuse: Discrepant Versions of Violence. Amsterdam: Benjamins.

Troemel-Ploetz, Senta. 1991. "Review Essay: Selling the Apolitical." Discourse \& Society, 2(4): 489-502.

Troutman, Denise. 2001. "African American Women: Talking That Talk." In Sonja L. Lanehart (ed.), Sociocultural and Historical Contexts of African American English, 211-237. Amsterdam: Benjamins.

Uchida, Aki. 1992. "When 'Difference' is 'Dominance': A Critique of the 'Anti-Power-Based' Cultural Approach to Sex Differences." Language in Society, 21: 547-568.

Vance, Carol, ed. 1984. Pleasure and Danger: Exploring Female Sexuality. London: Routledge \& Kegan Paul.

VanderStouwe, Chris. 2013. "Religious Victimization as Social Empowerment in Discrimination Narratives from California's Proposition 8 Campaign." Journal of Language and Sexuality, 2(2): 235-261.

Walker, Alice. 1983. In Search of Our Mothers' Gardens: Womanist Prose. San Diego: Harcourt Brace Jovanovich.

Walters, Keith. 1999. "'Opening the Door of Paradise a Cubit': Educated Tunisian Women, Embodied Linguistic Practice, and Theories of Language and Gender." In Mary Bucholtz, A. C. Liang, and Laurel A. Sutton (eds.), Reinventing Identities: From Category to Practice in Language and Gender Research, 200-217. New York: Oxford University Press.

Yerian, Keli. 1997. "From Stereotypes of Gender Difference to Stereotypes of Theory: A Response to Hayley Davis' Review of Deborah Tannen's Gender and 
Discourse." Language $\mathcal{E}$ Communication, 17(2): 165-176.

Zimman, Lal. 2009. "'The Other Kind of Coming Out': Transgender People and the Coming Out Narrative Genre." Gender and Language, 3(1): 53-80.

Zimman, Lal, Jenny L. Davis, and Joshua Raclaw, eds. In press. Queer Excursions:
Retheorizing Binaries in Language, Gender, and Sexuality. New York: Oxford

University Press.

Zimman, Lal, and Kira Hall. 2010.

"Language, Embodiment, and the 'Third Sex.' " In Carmen Llamas and Dominic

Watt (eds.), Language and Identities, 166-178.

Edinburgh: Edinburgh University Press. 